\title{
IMPORTANCE OF STUDENTS' PERSONALITY TRAITS FOR THEIR FUTURE WORK WITH PRESCHOOL CHILDREN
}

\author{
doc. dr . Sanja Tatalović Vorkapić \\ Irena Puljić \\ Faculty of Teacher Education in Rijeka, University of Rijeka \\ University of Rijeka \\ University Avenue 6 \\ 51000 Rijeka \\ Tel. 265-830 \\ e-mail: sanjatv@ufri.hr
}

\section{SUMMARY}

Preschool teachers' personality traits could have a strong significance for the quality of educational work with preschool children. Therefore, the aim of this study was to analyse personality traits of future preschool teachers within Big Five personality model: extraversion, neuroticism, consciousness, agreeableness and openness to experience. Besides, the relationship of their personality traits with academic year and the age of students was analysed too. Subjects were 64 students (age range from 19 to 23 years) enrolled at Early and Preschool Care and Education study program at Faculty of Teacher Education in Rijeka. As it was assumed, higher levels of extraversion, agreeableness and openness to experience and lower levels of neuroticism were determined. Also as it was expected, there was no significant correlation between students' generation and age with personality traits. In addition to research, this study emphasized the importance of the preschool teacher-child interaction in the kindergarten and the whole climate that (s)he creates within work with children, with guidelines for future studies.

Keywords: Big-five personality model, future preschool teachers, personality traits 
"How much do I know myself, and how much do I know each child individually? How and by what method do I support education for diversity? Do I allow the children to develop by their own program, or by my program?"

(Slunjski, 2003, p. 13)

\section{INTRODUCTION}

The work of preschool teachers with children of early and preschool age requires a significant amount of knowledge, skills and competences acquired through formal education. However, it could be often heard from parents, children or associates that some educators "have something special" what is the most needed characteristic for quality work with children and other participants in the educational process. In these situations it is very often that a child remembers those special preschool teachers for his/her whole life and remembers them happy, due to strong emotional connection which was created between them (Bauer, 2008). By this, preschool teachers become lifelong role models whose effects are hard to forget. Therefore, it is quite clear that process of early learning and teaching is a rather complex one, within which the extremely important element is exactly the personality of preschool teachers. In fact, a large number of studies has shown that teaching is not just a cognitive or technical process of acquiring knowledge, but very complex, personal and social set of processes and methods that concerns the whole person (Britzman, 2003; Cochran-Smith, 2005). Same as each child is different and it develops in his/her own specific way determined with his/her specific interests, learning ways, previous experience and socio-cultural context in which (s)he lives, preschool teachers' personalities differ significantly, too. Although preschool teachers have equal educational and psychological knowledge about working with children of preschool age, they have a different personality structure, lifestyle, interests, preferences, values, what affects their work with children at the implicit level. Accordingly, upon personal beliefs, attitudes and temperament of preschool teachers largely depend the following: a) how kindergarten environment will be organized; b) which materials will be offered and used; c) in what way and to what extent communication between children and between teachers and children will be encouraged; d) and what will be the attitude toward creativity and the interests of children with special needs (Slunjski, 2003). Studies that have used a qualitative methodology clearly demonstrated the extent to which different attitudes of educators determine the orientation of the dominant method of working in a kindergarten group (Vasconselos, 2002). All together present a strong argumentation for well-known affirmation that we are developing by help and in relation to significant others (Vygotsky, 1981), and these significant others in kindergarten are exactly preschool teachers.

It is therefore of utmost importance, especially as there is a small number of empirical studies on this topic (Yonemura, 1986), ask ourselves what is the structure of preschool teachers' personality, and more concrete of future preschool teachers' personality. Given the prominent differences, it is clear that in the early and preschool care and education there are no unambiguous and ready-made prescriptions, but preschool teachers' should develop 
their ability to manage and monitor the child and his/her needs. This is crucial in working with children, and directly relies on educators' personality traits.

\section{THE IMPORTANCE OF PRESCHOOL TEACHERS' PERSONALITY IN THE PROCESS OF EARLY AND PRESCHOOL CARE AND EDUCATION}

It is very important for educators to become aware of their role in the educational process, by raising awareness of the overall communication, which includes the organization of space and activities, setting the rules, and children decision-making rights. Inappropriate behaviour of teachers is often the result of their misconceptions between what they actually do and what they think they do within the interaction with children. Therefore, really improving the work of educators lies in the constant recognition, detection and awareness of their educational approach (Slunjski, 2003). So, it is very important for future preschool teachers to think reflectively about themselves, discover themselves, find out what they need to be and really want it be.

Work on themselves means recognizing the other unknown part of their individuality, discovering the hidden parts and making awareness of those unconscious parts within their personality. Therefore, the aim of self-work is not directly modifying their personality and correcting their behaviour. The real aim is to learn better and more successful exploitation of their personalities and behaviour in their private and professional lives (Brajša et al., 1999). In addition, by self-work educators get a more realistic insight into themselves and in their behaviour towards the child, not the diagnosis, and evaluation of their personalities. Every educator has different features of his/her personality, (s) he differently cope with various situations, and all of which affects the working style with preschool children.

At the same time, dealing with personal self-analysis, preschool teachers manage to influence on the development of others, in this case children. It should be emphasized that this does not mean to deny their own nature, but rather the opposite: to know and embrace their individuality in the way of recognizing their "strengths" for to be used in their work with children and identifying their "weaknesses" for to be controlled or overcome (Slunjski 2003). It is extremely important to know how to communicate and deal with the child as a "special personality". With the goal for a child to feel special and important, the preschool teacher must learn to listen to a child, appreciate him/her, respect his/her individuality and allow the child to experience educators' recognition of his/her self-worth. These skills, knowledge and competencies of educators become dominant only if his/her personality structure supports them and facilitates their application (Cartwright, 1999). If his/her personality structure is supportive, there is a very positive impact on the teacher-child interaction, and the overall atmosphere in the kindergarten group. This is important because studies have shown that children will only learn in an environment where they feel safe and well (Bauer, 2008). 


\section{FIVE-FACTOR MODEL OF PERSONALITY AND FUTURE PRESCHOOL TEACHERS}

Among the large number of theoretical models of personality, one of the most frequently used is the five-factor model of personality. Much of the research on the different samples was conducted using five factors indicating its ability of replication. Using qualifiers trait descriptors, Lewis Goldberg (1990) has made the largest systematic study of the big five factors. Key adjective markers of five factors (Goldberg, 1990) are: a) Extraversion: talkative, extraverted, assertive, direct, open versus shy, quiet, introverted, inhibited; b) Agreeableness: compassionate, kind, warm, understanding, honest opposite uncompassionate, unkind, rude, cruel; c) Conscientiousness: organized, neat, convenient, prompt, meticulous versus disorganized, sloppy, careless, superficial, impractical; d) Emotional stability: calm, relaxed, stable versus cranky, anxious, insecure; e) Intellect or Openness to experience: creative, imaginative, intellectual versus uncreative, unimaginative, not open to explore. This five-factor structure showed to be the same for men and women, durable through various techniques of factor analysis, and is replicated in the English language in many samples (Costa \& McCrae, 1985; Benet-Martinez \& John, 1998). Also, it was replicated in the Croatian language, on a sample of preschool teachers (Gović, 2012; Tatalović Vorkapić, 2012), and on the other samples (Kardum \& Smojver, 1993; Kardum, Hudek-Knežević \& Kola, 2005; Kardum, Gračanin \& Krapić, 2007).

Considering the stability of personality during adulthood, it was determined that as people get older, their personality becomes more stable and not so likely to be changed (Bratko, 2002). This happens especially after fifty years of age, when the average level of stability in extraversion, neuroticism, conscientiousness, agreeableness and openness almost not change at all. However, there are some previous changes. For example, there is a tendency of decline of openness, extraversion and neuroticism with age (Gović, 2012). At the same time, conscientiousness and convenience show a gradual increase (Tatalović Vorkapić, 2012).

Although average levels of personality traits changed just a little, they are important insofar because they demonstrate the changes during adulthood. The most consistent change is positive - with age people score lower on neuroticism or negative affect. With the transition from adolescence to a middle age, people feel less irritable, anxious and uncomfortable. Thus, negative affectivity consistently declines, as people get older. Contrary to decline of neuroticism with increasing age, conscientiousness and agreeableness are increased (Bratko, 2002).

What is particularly important for this study relates to the fact that the importance of the structure of preschool teachers personality is in the spotlight for monitoring process of early and preschool learning and teaching in kindergartens. It is, therefore, of great importance to monitor and analyse the personality of educators in practice, as well as students, i.e. future preschool teachers. The collected data not only would provide insight into the personality structure of future teachers during their studying, but they make possible their comparison with the results of educators in practice, as well as longitudinal follow-ups. By these studies it would be possible to answer on the following, 
very often asked question: What was the first, chicken or the egg? - I.e. whether students choose their profession in accordance with their existing personality traits, so the selected program is adapted to their personality; or the selection of future profession is independent of personality traits and only closely related to the interests, so the personality is later being adapted and changed in relation the demands of study and future career...? Although the answer is likely yes in both cases, this present study could not give answer on that question, but surely, it can present an objective and systematic introduction to the analysis of personality educators and future educators.

\section{RESEARCH AIM, PROBLEMS AND HYPOTHESES}

Given the importance of reasoned significance of personality traits of all participants within the process of teaching and learning (Vizek Vidović et al., 2003), including the educators themselves, it is essential to examine and analyse the personality traits of future preschool teachers within the five-factor model of personality: extraversion, neuroticism, conscientiousness, agreeableness and openness to experience. Accordingly, two problems will be analysed. First, levels of five personality dimensions will be determined. Second, the relationship between personality characteristics of future preschool teachers, their age and study generation will be analysed. Based on the relevant and recent literature it was assumed the following:

H1: With regard to previous research (Tatalović Vorkapić, 2012; Gović, 2012) it was expected to determine higher levels of extraversion, agreeableness, conscientiousness and openness to experience and lower level of neuroticism, due to the expected structure of the future preschool teachers' personality in relation to the requirements of preschool teachers' work.

H2: Given the previous research (Costa \& McCrae, 1994, Robins et al., 2001) it is not expected to determine the significant correlation between age and study generation with students' personality traits.

\section{METHOD}

\section{Participants}

The study was conducted on a sample of 64 students (all female) enrolled in the study program Early and Preschool Care and Education at Faculty of Teacher Education in Rijeka, University of Rijeka. The sample consisted of two study generations, both studying as the freshmen: 36 students of the first study generation and 28 students of the second study generation. The mean age was $\mathrm{M}=19.8(\mathrm{SD}=1.12)$. The youngest respondent was 19 years old and the oldest was 23 years old. 


\section{Measurement and procedure}

In this study, standardized questionnaire for measuring five dimensions of personality, Big Five Inventory (BFI; Benet-Martinez \& John, 1998), adapted to Croatian language (Kardum, Hudek-Knežević and Kola, 2005) has been applied. All BFI-subscales showed satisfactory levels of reliability by calculating Cronbach's alpha coefficients: extraversion $(\mathrm{r}=0.785)$, neuroticism $(\mathrm{r}=0.796)$, conscientiousness $(\mathrm{r}=0.804)$, agreeableness $(\mathrm{r}=0.689)$ and openness to experience $(\mathrm{r}=0.807)$. Results of the Kolmogorov-Smirnov test showed that the distributions of extraversion $(\mathrm{K}-\mathrm{Sz}=1.61, \mathrm{p}=0.135)$, neuroticism ( $\mathrm{K}-\mathrm{Sz}=0.768, \mathrm{p}=0.597)$, conscientiousness $(\mathrm{K}-\mathrm{Sz}=0.812, \mathrm{p}=0.525)$, agreeableness ( $\mathrm{K}-$ $\mathrm{Sz}=0.815, \mathrm{p}=0.686)$ and openness to experience $(\mathrm{K}-\mathrm{Sz}=0.572, \mathrm{p}=0.899)$ did not significantly differ from the normal distribution, which enables the use of parametric tests in further statistical analysis.

The survey was conducted during the semester and student participation was completely anonymous and voluntary. Completing the survey lasted for about $10 \mathrm{~min}$ utes. For statistical analyses of collected data, a computer program Statistica was used. Descriptive statistics was applied with the aim of analyzing future preschool teachers' personalities. To analyze the relationship between personality traits of future educators, study generation, and the students' age, correlation analysis was run.

\section{RESULTS AND DISCUSSION}

\section{Personality traits of future educators: extraversion, neuroticism, conscientiousness, agreeableness and openness to experience}

Basic statistical parameters of the personality traits of future preschool teachers such as mean, standard deviation, minimum and maximum (range) of results for each of the five personality dimensions have been presented in the Table 1 and Figure 1. Since it was assumed that students would show higher levels of extraversion, agreeableness, conscientiousness and openness to experience, and lower level of neuroticism than its peers, it is evident that the initial hypothesis was confirmed.

\section{Extraversion}

Future preschool teachers have achieved an average overall score on a subscale of extraversion $M=29.095$, what is higher as compared to American students who showed an average overall score on the same scale $M=26$ (Srivastava et al., 2003). This is a significant advantage since students enrolled at study program Early and Preschool Education will be working with children. The assumption is that the young people who choose to study for preschool teachers possess personality traits that are adequate to those needed 
for working with children. In other words, it is expected to be open, empathetic, talkative, friendly, flexible, etc. Furthermore, comparing these results with the results set out in the studies of preschool teachers in practice (Gović, 2012; Tatalović Vorkapić, 2012), it could be seen that scores of students are lower than the scores of preschool teachers, but the difference is not so big $(M=29.53$ and $M=0.77)$. Educators in practice are described as talkative, active, sociable and optimistic what was expected and not so different from the characteristics of students.

Table 1: Basic descriptive statistical parameters of future preschool teachers' personality traits: Extraversion, Neuroticism, Conscientiousness, Agreeableness, and Openness to Experience

\begin{tabular}{|l|l|l|l|}
\hline Five personality dimensions & M & SD & RANGE \\
\hline Extraversion & 29.095 & 4.795 & $15-37$ \\
\hline Neuroticism & 22.438 & 5.203 & $8-35$ \\
\hline Conscientiousness & 32.391 & 5.160 & $17-45$ \\
\hline Agreeableness & 34.703 & 4.396 & $27-43$ \\
\hline Openness to experience & 38.531 & 5.460 & $26-49$ \\
\hline
\end{tabular}

\section{Neuroticism}

Neuroticism is characterized by the tendency of anxiety, negative ideas, mood variability and frequent ups and downs in social relationships due to frequent dissatisfaction and high reactivity. Students in this study, reached an average value of $M=22.438$ at the dimension of neuroticism, which is less than the average value of $M=26.56$, that was obtained by the students in the foreign study (Srivastava et al., 2003). It is expected that students are aware of the requirements of preschool teachers' work and thus they were led by that when choosing a future profession. When working with children, preschool teachers need to be patient, considerate, focused on the child and full of positive emotions. A person with a high score on a scale of neuroticism is difficult to achieve these characteristics, because (s) he has a great amount of negative emotions which are draining her/his energy out what directly affects the child in a negative way. Preschool teachers' work requires the full engagement of all the senses, so it is important for them to know how to control their internal states and emotions. Since there is a general decline of neuroticism with years, it is expected that average value of neuroticism will be reduced during working experience years. This fact was confirmed by the results of previous research on preschool teachers (Gović, 2012, Tatalović Vorkapić, 2012) who showed a mean value of just $M=18$ on neuroticism subscale. The reasons for neuroticism decline lied in the fact that eventually, the anxiety caused by changes in the body has been totally lost due to maturation process. In addition, it is assumed that preschool teachers have already formed personality structure and regulated life conditions what helps them to reduce negative emotions. 
Figure 1. Boxplots of all five personality dimensions of the future preschool teachers

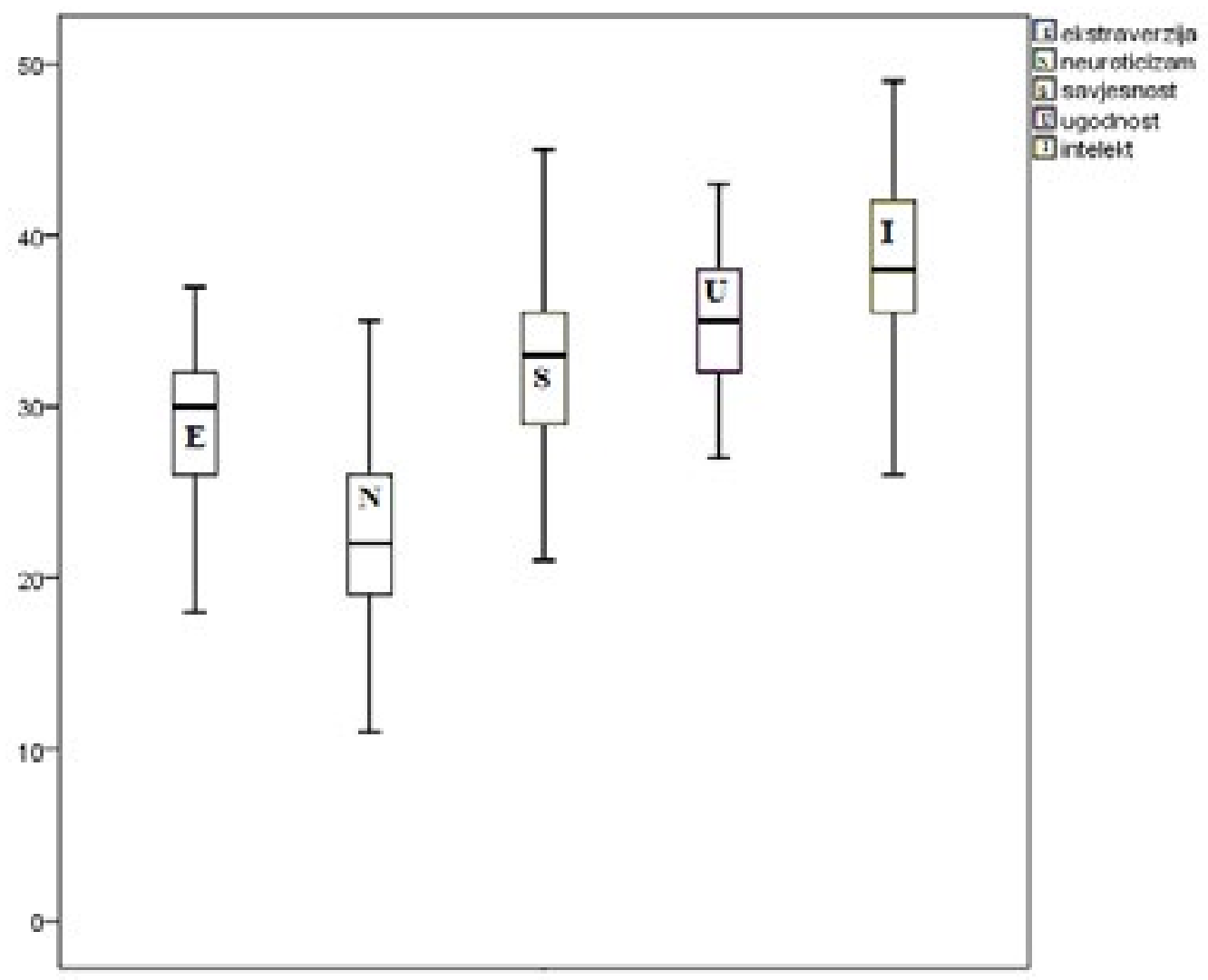

\section{Conscientiousness}

Conscientious people are hard-working and goal-oriented, and their behaviour reliably results in more favourable outcomes in all fields of life. Conscientiousness is associated with accuracy, the desire for success and self-discipline. The average overall score on conscientiousness subscale of $\mathrm{M}=32.391$ achieved by the students in this study is higher than the results that have been achieved by peers in other studies $(M=31.05$; Srivastava et al., 2003). In the life of a child, the teacher presents the person in who the child sees a role model and follows the way of responding and acting in everyday situations (Cartwright, 1999). In addition, it is important that the teacher is accurate and self-disciplined, thereby creating an atmosphere of safety. If a child does not know what to expect from the teachers, it experienced a big disproportion between the expected and committed. Therefore, it is not surprising that future preschool teachers achieve higher results on this dimension as opposed to students who are enrolled in other degree programs. In addition, the research on preschool teachers in practice (Tatalović Vorkapić, 2012) showed that educators in this dimension achieve higher scores $(M=35.3)$ than students do. Similar results were obtained at the sample of the educators $(M=36.1)$ in the study 
of Gović (2012). Results were expected and desirable because teachers work in teams, i.e. two preschool teachers work in one educational group. Being conscientious, reliable, accurate and neat helps maintain positive and good relationship between two preschool teachers and between teachers, parents and children. Teamwork is a main feature of work in kindergartens, as educators mutually shared responsibility for one educational group that are dedicated to, and at the same time collaborate with parents. Given that this is, so called, instrumental personality trait that is more under influence of the environment as opposed to extraversion and neuroticism. Therefore, it is possible that later, it is changed under the influence of job requirements. However, longitudinal research could give the clearer answer to this question, which may be one of the guidelines for future research.

\section{Agreeableness}

To live in harmony with other people is the main motto of agreeable people. So, agreeable person will withdraw from social conflict, and (s)he will try to solve the conflict using her/his social skills. Altruism and harmonious social interaction are the main objectives of agreeable people. When working with children, it is expected that the teacher will show gentleness, patience, kindness, warmth, honesty and other qualities which present the basics for creating a positive relationship with a child. According to Cartwright (1999) and Šagud (2006) warmth, love, care and empathy are the most important characteristics of a good educator. Therefore, future preschool teachers achieve the result of $M=34.703$, which is higher than the result obtained in a peer sample of American students of $M=32.76$ (Srivastava et al., 2003). In addition to the climate in the preschool group, dimension of agreeableness has a major part in the overall functioning of the kindergarten. Smiling, approachable, warm and empathic educator creates a constructive relationship with parents, children, and in return gets a lot of their confidence. The parent is not easy to leave his/her child for almost all day, but if (s)he is sure that his/her child is satisfied, protected and has the opportunity to learn, it would be easier for him/her to overcome the separation with the child. It is necessary to strive for the understanding of parental demands, and understood their concern about the children, what is enhanced by providing continuous feedback on all activities in kindergarten. Determined findings about this dimension among preschool teachers (Tatalović Vorkapić, 2012; Gović 2012) confirm the significance and importance of the presence of these personality dimensions in educators $(M=36)$.

\section{Openness to Experience}

Open individuals show more interests towards artistic and intellectual subjects, they have a greater need for variety, imagination, flexibility and innate curiosity. It is believed that people high on this dimension tend not to ignore previously experienced stimuli, while less open people have a narrower awareness and they easily ignore stimuli. The result obtained in this study among students who are future preschool teachers are not significantly different from the determined age norms for this dimension in foreign students, which is not surpris- 
ing given the emphasis on this property during the study ( $M=39.2$; Srivastava et al., 2003). By this, students acquire the habit of working on new projects and recognize the importance of research in the life of a preschool child. With their own imagination and flexibility they become co-designers in the children's experience of the world (Slunjski, 2008), and in the expression of imagination and pre-operational thought (Tatalović Vorkapić, 2012). Comparing the scores of students with the results of educators in practice, some differences could be observed ( $M=39.65$; Gović, 2012) and ( $M=41.03$; Tatalović Vorkapić, 2012). The fact is that educators recognize children interests by years, which are rather various. Therefore, it is important to expand their own interests and nourish openness to new experiences and situations, so they could be able to adequately respond on satisfying children needs.

\section{THE RELATIONSHIP BETWEEN FUTURE PRESCHOOL TEACHERS' PERSONALITY TRAITS, STUDY GENERATION AND STUDENTS' AGE}

With the aim of analyzing the relationship between all five personality traits (extraversion, neuroticism, conscientiousness, agreeableness and openness to experience) and study generation and students' age, correlation analysis has been conducted. Table 2 shows the calculated Pearsons' correlation coefficients between key variables and their levels of significance.

Generally, established findings confirmed the null hypothesis about the relationship between personality traits, study generation and students' age. Therefore, there is no significant relationship determined between personality traits and age. In some Croatian studies (Bratko 2002; Gović 2012) low correlations have been determined between all five factors and age, except in the case of extraversion, where a rather higher correlation has been determined (Gović 2012). In a survey conducted by Bratko (2002) a significant association between neuroticism and age was established, possibly due to maturation processes. In addition, application of the NEO Personality Inventory (Costa \& McCrae, 1985) low correlations between age and personality in the U.S. sample of adult subjects were determined (from $r=-0.12$ to $r=-0.19)$. Correlations determined in this study are within this range. In addition, no significant correlation has been found between the two study generations and personality traits. Correlation analysis findings implicated the need for testing all students enrolled at program Early and Preschool education, thus obtaining a greater age range, and then the possibility of more detailed analysis of personality with regard to possible age differences.

Table 2: Correlation matrix of personality traits, study generation and students' age

\begin{tabular}{|l|l|l|l|l|l|}
\hline & Extraversion & Neuroticism & Conscientiousness & Agreeableness & $\begin{array}{l}\text { Openness to } \\
\text { experience }\end{array}$ \\
\hline Studygeneration & -0.193 & 0.188 & -0.215 & -0.149 & -0.040 \\
\hline Age & 0.071 & 0.037 & -0.021 & -0.044 & -0.059 \\
\hline${ }^{*} \mathrm{p}<0.05,{ }^{* \star} \mathrm{p}<0.01$
\end{tabular}




\section{CONCLUSION}

The findings of this study have confirmed the initial hypotheses. Higher levels of Extraversion, Agreeableness, Conscientiousness and Openness to experience, and reduced levels of Neuroticism were determined compared to the normative sample. These findings could be explained by the expected structure of the personality of future preschool teachers in relation to the requirements of preschool teachers' work. Furthermore, no significant correlations have been found between study generation and students' age with any of the investigated personality traits. In addition, the results showed that all personality dimensions except neuroticism were higher in this sample in comparison to the levels of personality traits in other students. This finding would go in favour of the thesis that the future vocation has been chosen in relation to the existing personality traits, but as such requires empirical verification, as it was outlined before. Comparison between these findings and the results of personality traits among preschool teachers showed a rather high similarity, what implied at validity and reliability of this study. Even though a relatively small and selective sample has been used in this study, the possible contribution of this and similar studies lies in the fact that preschool and primary school teachers' personalities are very important in a child's life. They are very impressive role models of expressing the emotions, shaping the thoughts and behavioural patterns, and observing them children learn through modelling. In doing so, preschool teachers' personality, their instinctive kindness, integrity and overall dynamic interest for life and teaching of children significantly affect the development of children and on what/how they learn. In this way, they remain permanently in the memory of children, and how child memory will be coloured significantly depends on the preschool teachers, what presents a huge responsibility but also a continuous, inspiring challenge for educators (Cartwright, 1999).

\section{ACKNOWLEDGEMENTS}

We wish to thank Professor Igor Kardum, $\mathrm{PhD}$, for the possibility of applying the Big Five Inventory and students at Faculty of Teacher Education who participated in the study.

\section{BIBLIOGRAPHY}

1. Bauer. S. (2008). What Qualities Should Preschool Teachers Have? Jakarta Post, September.http://www.tutortime.co.id/images/download/Teachers+role.pdf

2. Benet-Martinez, V. \& John, O. P. (1998). Los cincos grandes across cultures and ethnic groups: Multitrait multimethod analyses of the Big Five in Spanish and English. Journal of Personality and Social Psychology, 75; 729-750.

3. Brajša, P., Brajša Žganec, A. \& Slunjski, E. (1999). Tajna uspješnog roditelja i odgojitelja (The secret of successful parents and educators). Pula: C.A.S.H. 
4. Bratko, D. (2002). Kontinuitet i promjene ličnosti od adolescencije do rane odraslosti: Rezultati longitudinalnog istraživanja (Personality Continuity and Change from Adolescence to Young Adulthood: Longitudinal Study). Društvena istraživanja, 4-5(60-61); 623-640.

5. Britzman, D. (2003). Practice makes practice: A critical study of learning to teach. Albany, NY: State University of New York Press.

6. Cartwright, S. (1999). What makes good early childhood teachers? Young Children, 54(4); 218-221.

7. Cochran-Smith, M. (2005). The new teacher education: For better or for worse? 2005 presidential address. Educational Researcher, 34(7); 3-17.

8. Costa, P.T., Jr., \& McCrae, R. R. (1985). The NEO personality inventory manual. Odessa, FL: Psychological Assessment Resources.

9. Costa, P.T., Jr., \& McCrae, R.R. (1994). Set like plaster? Evidence for the stability of adult personality. U: T. F. Heathherton i J. L. Weinberger (Ur.), Can personality change? (21-40). Washington, DC: American Psyhological Association.

10. Costa, P. T., Jr. \& McCrae, R. R. (1997). Longitudinal stability of adult personality. U: R. Hogan, J. Johnson i S. Brrigs (Ur.), Handbook of Personality Psychology (269 290). Academic Press, New York.

11. Goldberg, L. R. (1990). An alternative „description of personality“: The big-five factor structure. Journal of Personality and Social Psychology, 59; 1216-1229.

12. Gović, A. (2012). Doživljaj zanesenosti na poslu i osobine ličnosti odgajatelja (The flow experience at work and personality traits of preschool teachers). Diplomski rad. Učiteljski fakultet, Sveučilište u Rijeci, Rijeka.

13. Kardum, I., Gračanin, A. \& Krapić, N. (2007). Odnos dimenzija petofaktorskog modela ličnosti i raspoloženja (Relations Between Dimensions of the Five-Factor Model of Personality and Mood). Društvena istraživanja, 1-2(87-88); 135-156.

14. Kardum, I., Hudek-Knežević, J. \& Kola, A. (2005). Odnos između osjećaja koherentnosti, dimenzija petofaktorskog modela ličnosti i subjektivnih zdravstvenih ishoda (The relationship between sense of coherence, five-factor personality traits and subjective health outcomes). Psihologijske teme, 14(2); 79-94.

15. Kardum, I. \& Smojver, I. (1993). Petofaktorski model strukture ličnosti: izbor deskriptora $\mathrm{u}$ hrvatskom jeziku (Five-factor model of personality structure: the choice of descriptors in the Croatian language). Pedagoški fakultet u Rijeci. Godišnjak Zavoda za psihologiju, 2; 91-100.

16. McCrae, R.R. \& Costa, P. T. Jr. (1990). Personality in adulthood. The Guilford Press, New York.

17. Robins, R.W.., Fraley, R.C., Roberts, B.W. \& Trzesniewski, K.H. (2001). A longitudinal study of personality change in young adulthood. Journal of Personality, 69; 617-640.

18. Slunjski, E. (2003). Devet lica jednog odgajatelja (Nine faces of one preschool teacher). Zagreb: Mali profesor.

19. Slunjski, E. (2008). Dječji vrtić - zajednica koja uči: mjesto dijaloga, suradnje i zajedničkog učenja (Kindergarten - the learning community: a place of dialogue, cooper- 
ation and mutual learning). Spektar media, Zagreb.

20. Srivastava, S., John, O. P., Gosling, S. D. \& Potter, J. (2003). Development of personality in early and middle adulthood: Set like plaster or persistent change? Journal of Personality and Social Psychology, 84(5); 1041-1053.

21. Šagud, M. (2006). Odgajatelj kao refleksivni praktičar (Educator as reflective practitioner). Petrinja: Visoka učiteljska škola.

22. Tatalović Vorkapić, S. (2012). The Significance of Preschool Teacher's Personality in Early Childhood Education: Analysis of Eysenck's and Big Five Dimensions of Personality. International Journal of Psychology and Behavioral Sciences, 2 (2); 28-37.

23. Vasconcelos, T. (2002). "I am like this because I just can't be different..." Personal and professional dimensions of Ana's teaching: Some implications for teacher education. U: D. Rothenberg (Ur.), Proceedings of the Lilian Katz Symposium (191-199). Early Childhood \& Parenting (ECAP) colaborative University of Illinois, Urbana-Champaign, USA.

24. Vizek-Vidović, V., Vlahović-Štetić, V., Rijavec, M. \& Miljković, D. (2003). Psihologija obrazovanja (Educational Psychology). Zagreb: IEP-Vern.

25. Vygotsky, L. S. (1981). The genesis of higher mental functions. U: J. V. Wertsch (Ur.), The concept of activity in soviet psychology (144-188). New York: Sharpe.

26. Yonemura, M. (1986). A teacher at work: Professional development and the early childhood educator. New York: Teachers College Press. 